\title{
Defective IL-17- and IL-22-dependent mucosal host response to Candida albicans determines susceptibility to oral candidiasis in mice expressing the HIV-1 transgene
}

Mathieu Goupil ${ }^{1}$, Vincent Cousineau-Côté ${ }^{1}$, Francine Aumont ${ }^{1}$, Serge Sénéchal ${ }^{1}$, Louis Gaboury ${ }^{2,6}$, Zaher Hanna ${ }^{3,4,5}$, Paul Jolicoeur ${ }^{1,4,5}$ and Louis de Repentigny ${ }^{1 *}$

\begin{abstract}
Background: The tissue-signaling cytokines IL-17 and IL-22 are critical to host defense against oral Candida albicans infection, by their induction of oral antimicrobial peptide expression and recruitment of neutrophils. Mucosal Th17 cells which produce these cytokines are preferentially depleted in HIV-infected patients. Here, we tested the hypothesis that defective IL-17- and IL-22-dependent host responses to C. albicans determine the phenotype of susceptibility to oropharyngeal candidiasis (OPC) in transgenic (Tg) mice expressing HIV-1.

Results: Naiive CD4+ T-cells and the differentiated Th1, Th2, Th17, Th1Th17 and Treg lineages were all profoundly depleted in cervical lymph nodes (CLNs) of these Tg mice. However, naive CD4+ cells from $\mathrm{Tg}$ mice maintained the capacity to differentiate into these lineages in response to polarizing cytokines in vitro. Expression of $1117, \| 122$, S100a8 and CCl20 was enhanced in oral mucosal tissue of non-Tg, but not of Tg mice, after oral infection with C. albicans. Treatment of infected Tg mice with the combination of IL-17 and IL-22, but not IL-17 or II-22 alone, significantly reduced oral burdens of C. albicans and abundance of Candida hyphae in the epithelium of tongues of infected $\mathrm{Tg}$ mice, and restored the ability of the Tg mice to up-regulate expression of S100a8 and Cc/20 in response to C. albicans infection.
\end{abstract}

Conclusions: These findings demonstrate that defective IL-17- and IL-22-dependent induction of innate mucosal immunity to C. albicans is central to the phenotype of susceptibility to OPC in these HIV transgenic mice.

Keywords: Candida albicans, CD4+ T-cells, Th17, IL-17, IL-22, HIV-1, Transgenic mice

\section{Background}

Oropharyngeal candidiasis (OPC) is the most frequent opportunistic fungal infection encountered in patients infected with the human immunodeficiency virus (HIV) [1]. Although highly active antiretroviral therapy has sharply reduced the incidence of OPC in developed countries [2], it remains a common co-infection in many developing regions where people living with HIV/AIDS have limited access to therapy [3-5]. The critical impairments of mucosal immunity which cause susceptibility

\footnotetext{
* Correspondence: louis.de.repentigny@umontreal.ca

'Department of Microbiology, Infectious Diseases and Immunology, Faculty of Medicine, University of Montreal, C.P. 6128, succursale Centre-Ville,

Montreal, Quebec H3C 3J7, Canada

Full list of author information is available at the end of the article
}

to OPC in HIV-infection are only partly understood [6,7]. A correlation has been established in HIV infection between symptomatic OPC and reduced CD4+ cell count [8-10], HIV viral load [8,9], and the development of AIDS [10]. Moreover, a dominant role for IL-17-producing Th17 cells in host defense against OPC was demonstrated by Conti et al. [11], who found that Candida infection of the tongue was less severe in mice lacking IL-12p35 than in mice lacking IL-23p19, the latter also displaying impaired neutrophil recruitment to the mucosa. Conti et al. [11] also reported defective mucosal expression of murine $\beta$-defensin 3, S100A8 and CCL20 in IL-17RA ${ }^{\mathrm{KO}}$ mice. Furthermore, Th17 signature genes are induced early after oral $C$. albicans infection of 
immunocompetent mice $[11,12]$. In addition to IL-17, IL-22 production by Th17 cells also contributes to early host defense against $C$. albicans $[11,13,14]$, and IL-17 and IL-22 cooperatively enhance expression of antimicrobial peptides by keratinocytes [15-19]. Induction of this protective Th17 response is dependent on recognition of C. albicans by the mannose receptor [20,21], and dectin1 and -2 signaling through the Syk/CARD9 cascade [22-24], leading to IL-23 but not IL-12 production by antigen-presenting cells [25]. In normal humans, memory CD4+ T-cells specific for $C$. albicans reside mainly in the Th17 subset $[25,26]$.

It is now well established that CCR6+ Th17 cells, including those specific to C. albicans, are highly permissive to HIV-1 infection in vitro and are preferentially depleted in peripheral blood of HIV-infected patients [27-31]. Evidence has also been presented showing that Th17 cells are depleted in the gastrointestinal mucosa of persons infected with HIV [32-34]. There has been much speculation about defective Th17 responses to oral $C$. albicans infection in the context of HIV infection [35-37], which would result in a lack of the critical cytokines required to up-regulate the innate mucosal response, and consequently cause susceptibility to OPC [38]. However, no experimental evidence has as yet been presented to support this hypothesis.

Using a model of oral Candida infection in transgenic (Tg) mice expressing HIV-1 in CD4+ T-cells, dendritic cells (DCs) and macrophages, which closely mimics the clinical and pathological features of candidal infection in human HIV infection [39], we have previously shown that altered CD4+ T-cell phenotype and function determine susceptibility to chronic carriage of C. albicans in these Tg mice $[40,41]$. Furthermore, DCs from these Tg mice display an immature phenotype and defective antigen presentation $[40,42]$. In the present study, we asked whether $\mathrm{CD} 4 \mathrm{C} / \mathrm{HIV}^{\text {MutA }} \mathrm{Tg}$ mice have a defective capacity to induce protective Th17-dependent mucosal responses to oral infection with $C$. albicans. Here we show that depletion of the differentiated Th1, Th2, Th17, Th1Th17 and Treg CD4+ T-cell lineages in these Tg mice results from depletion of naive CD4+ T-cell precursors, and not from an inability of naïve CD4+ cells to differentiate in response to polarizing cytokines in vitro. We further demonstrate that $\mathrm{Tg}$ mice are unable to up-regulate expression of the Il17, Il22, S100a8 and Ccl20 genes in oral mucosal tissue in response to oral $C$. albicans infection, and that combined treatment of infected Tg mice with IL-17 and IL-22 restores the ability of the Tg mice to up-regulate expression of S100a8 and Ccl2O and reduces oral burdens of $C$. albicans. Defective IL-17- and IL-22-dependent induction of innate mucosal immunity to $C$. albicans is therefore central to the phenotype of susceptibility to OPC in these HIV transgenic mice.

\section{Results}

CD4+ T-cell subsets are all profoundly depleted in CD4C/HIV ${ }^{\text {MutA }}$ Tg mice

Phenotyping of cervical lymph node (CLN) CD4+ Tcells, harvested ex vivo from Tg mice 7 or 70 days after infection or not with $C$. albicans, revealed significantly enhanced percentages of Th17, Th1Th17 and Treg subsets but strikingly depleted absolute numbers of Th1, Th2, Th17, Th1Th17 and Treg cell populations compared to non-Tg mice (Figure 1). Furthermore, a significant expansion in absolute numbers of the Th2 subset observed in non-Tg mice 7 days after infection with $C$. albicans was absent in the $\mathrm{Tg}$ mice (Figure 1). Interestingly, mean surface expression of CCR6 by Th17 cells $(\mathrm{CD} 4+\mathrm{CXCR} 3+\mathrm{CCR} 4+\mathrm{CCR} 6+)$ was not significantly altered $(p>0.05)$ by HIV-1 transgene expression, indicating that this determinant of Th17 cell migration was preserved in the $\mathrm{Tg}$ mice.

\section{Polarization of CD4+ T-cells and production of cytokines in vitro}

To determine if expression of the HIV-1 transgene alters the differentiation of naive CD4+ T-cells into specific subsets, we next assessed expression of signature CD4+ T-cell subset genes and production of cytokines after differentiation of naive splenic cells in vitro. Numbers of naïve CD4+ T-cells recovered per spleen were sharply diminished in $\mathrm{Tg}$ compared to non- $\mathrm{Tg}$ mice $(1.5 \pm 0.2$ versus $\left.7.9 \pm 0.4 \times 10^{5}, \mathrm{p}<0.0001 ; \mathrm{N}=11\right)$, consistent with previous findings in CLNs of Tg mice [40]. The predicted up- or down-regulation of signature gene expression $[43,44]$ was found after incubation of naive cells from both non-Tg and Tg mice with cocktails of differentiating cytokines and blocking antibodies specific to the Th1, Th2, Th17 and Treg subsets (Figure 2). However, HIV-1 transgene expression nevertheless altered gene expression profiles of the polarized subsets (Figure 2). Compared to non-transgenic controls, polarized Th17 cells from $\mathrm{CD} 4 \mathrm{C} / \mathrm{HIV}^{\text {MutA }} \mathrm{Tg}$ mice displayed increased expression of Ahr, Il22 and Foxp3, and polarized Treg cells had enhanced expression of Ahr and Il17a (Figure 2), suggesting that expression of the HIV-1 transgene in CD4+ T-cells may produce an intermediate Th17-Treg phenotype under these differentiating conditions. Although Gata3 expression was lower in differentiated Th1 cells from $\mathrm{Tg}$ mice (Figure 2), the most relevant finding was that expression of this Th2 signature gene was unaffected by transgene expression in Th2 differentiating conditions (Figure 2). These findings demonstrate that naive $\mathrm{CD} 4+$ cells from $\mathrm{Tg}$ mice maintain the overall capacity to differentiate into specific subsets in vitro. Furthermore, HIV-1 transgene expression did not significantly alter cytokine production in supernatants of cells differentiated or not into specific subsets $(p>0.05)$ 


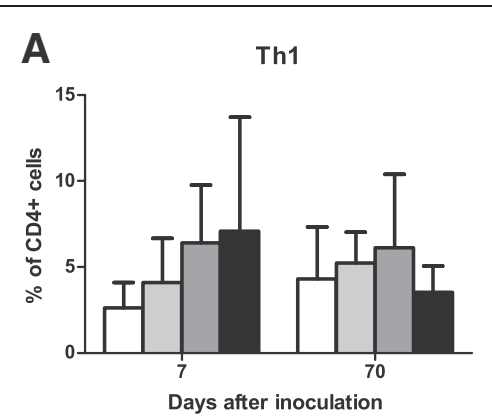

Th2

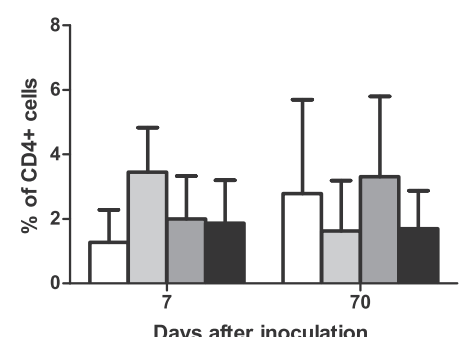

Th17

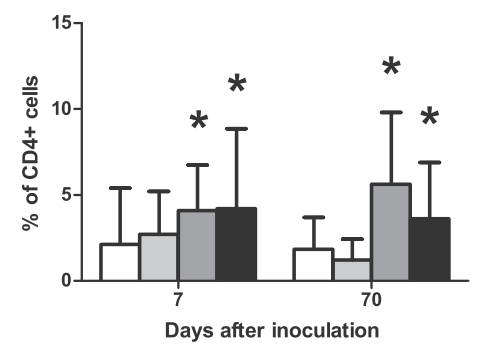

Th1Th17
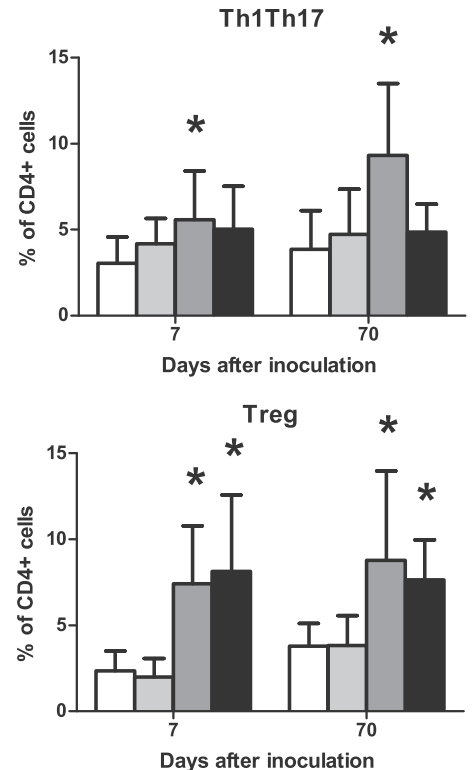

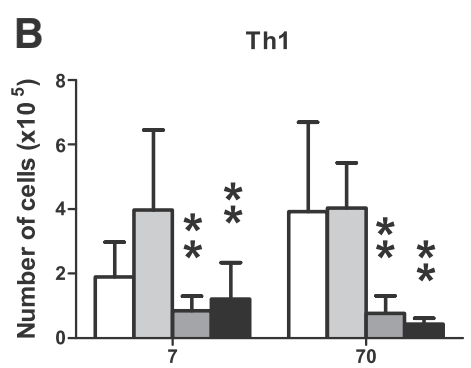

Days after inoculation

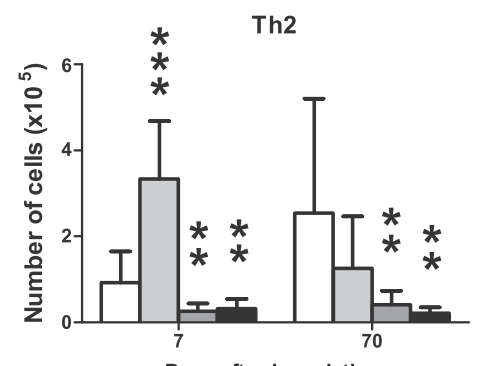

Days after inoculation

Th17

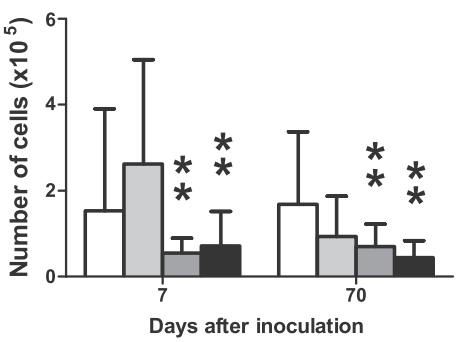

Th1Th17

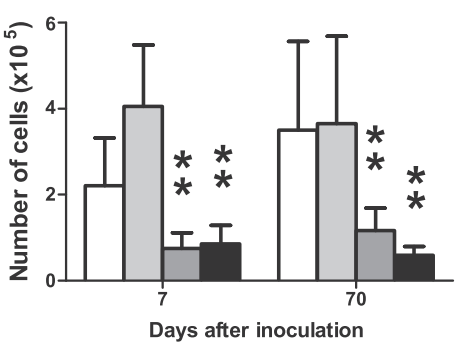

Treg

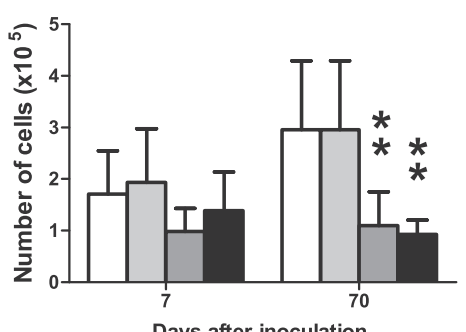

ays after inoculation

Figure 1 Immunophenotypes of cervical lymph node CD4+ T-cell subsets in CD4C/HIVutA $\mathrm{Tg}$ and non-Tg control mice. CLNs were harvested 7 or 70 days after oral infection or not with Candida albicans. Data are expressed as (A) the percentage of CD4+ T-cells or as (B) absolute numbers of cells, and are the mean \pm SD of 4 to 13 independent experiments. ${ }^{*}$, greater $(p<0.05)$ than non-Tg mice; **, lower $(p<0.05)$ than non-Tg mice; ${ }^{* * *}$, greater $(p<0.05)$ than uninfected non-Tg mice. 


\section{Signature gene expression of in vitro-polarized CD4 ${ }^{+}$T-cells}

Th1 polarization conditions

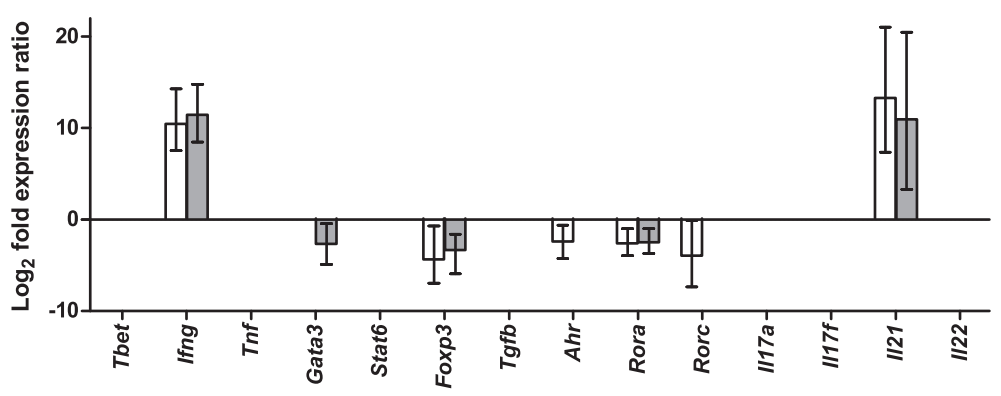

Th2 polarization conditions

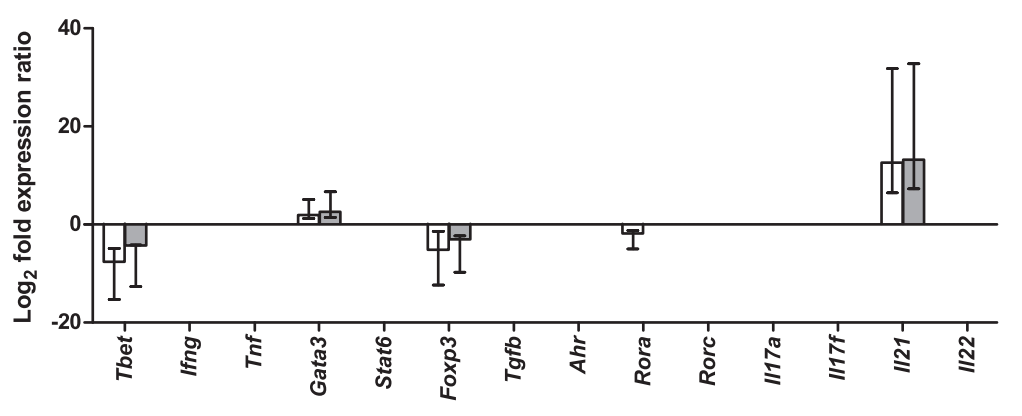

Th17 polarization conditions

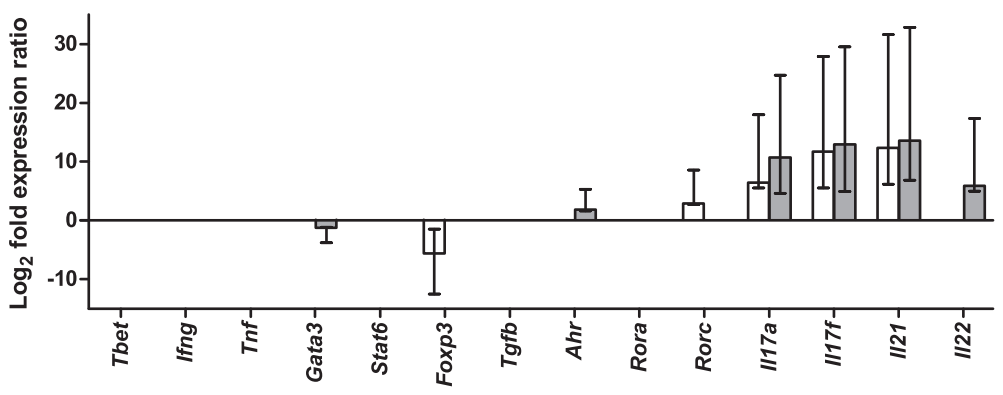

Treg polarization conditions

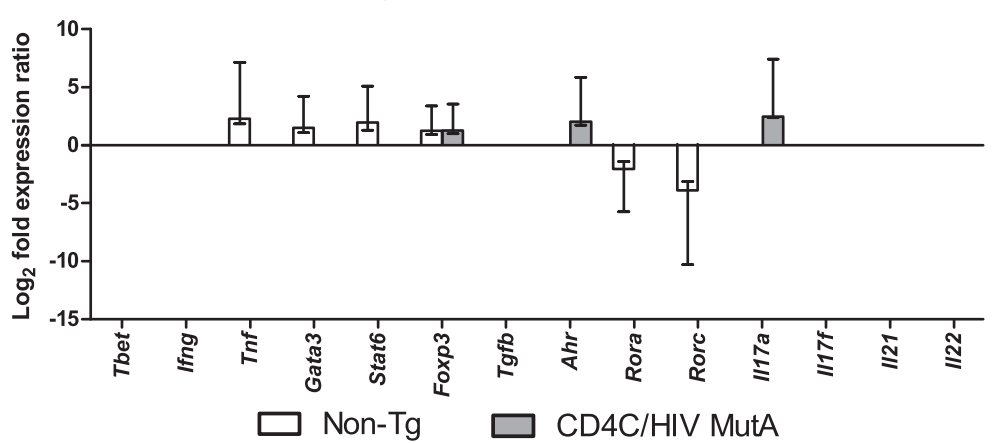

Figure 2 qRT-PCR analysis of signature genes of CD4+ T-cell subsets polarized in vitro. Naive CD4+ precursors were harvested from $\mathrm{CD} 4 \mathrm{C} / \mathrm{HIV}^{\mathrm{MutA}} \mathrm{Tg}$ and non-Tg mice, and incubated with subset-specific differentiating cytokines and blocking antibodies. Bars represent the mean \pm standard error range of significantly $(p<0.05)$ up- or down-regulated genes compared to that of control naive cells from non-Tg mice, incubated without cytokines and antibodies. In all differentiating conditions, gene expression of IL-4 and IL-10 was not significantly different $(p>0.05)$ from control. Data are from 6 independent experiments. 
(Figure 3). Production of IFN- $\gamma$ and IL-17A by naive CD4+ cells from Tg and non-Tg mice increased comparably in response to Th1 and Th17 differentiating conditions (Figure 3). Therefore, using identical numbers of naïve CD4+ T-cells from $\mathrm{Tg}$ and non-Tg mice, in vitro differentiated CD4+ T-cell lineages from Tg mice maintained their capacity to produce the critical cytokines required for a protective adaptive immune response to $C$. albicans.

\section{IL-17 and IL-22 treatment augments resistance to oral} candidiasis and oral mucosal expression of calprotectin in CD4C/HIV ${ }^{\text {MutA }}$ Tg mice

Oral burdens of $C$. albicans were significantly increased $(\mathrm{p}<0.05)$ in $\mathrm{Tg}$ compared to non-Tg mice on days 3-17 after inoculation, as reported previously [39], and treatment of the Tg mice with the combination of IL-17 and IL-22 reduced oral burdens on days 5-12 compared to untreated Tg controls (Figure 4A). Nevertheless, on days 3-17 after inoculation, oral burdens of C. albicans in Tg mice treated with the combination of IL-17 and IL-22 remained significantly greater $(\mathrm{p}<0.05)$ than in untreated control non-Tg mice, showing that this cytokine treatment did not fully restore resistance to oral candidiasis. Interestingly, treatment with IL-17 alone only produced a transient reduction $(\mathrm{p}<0.05)$ of oral burdens on day 7 (Figure 4B), while IL-22 alone was without significant effect $(\mathrm{p}>0.05)$ (Figure $4 \mathrm{C})$, showing that IL-17 and IL-22 are both required and non-redundant for mucosal host defense against C. albicans.
Histopathology of tongues of untreated control Tg mice, conducted 7 days after oral inoculation of C. albicans, showed the expected dense hyphal penetration of the epithelium of the entire dorsum of the tongue, accompanied by occasional inflammatory cell infiltrates [39] (Figure 5B1,2). In contrast, in Tg mice treated with the combination of IL-17 and IL-22, the density of Candida hyphae was sharply diminished, and, in most of the epithelium, hyphae were entirely absent (Figure 5A1,2). Compared to untreated $\mathrm{Tg}$ controls (Figure 5B1), this cytokine treatment did not induce an additional influx of polymorphonuclear leukocytes (PMNs) or other inflammatory cells to the epithelium of these $\mathrm{Tg}$ mice at this time point of infection (Figure 5A1). In the control non-Tg mice, which at day 7 are resolving primary Candida infection (Figure 4A) [39], only one or two small foci of Candida hyphae were found in the keratinized layer of the epithelium of three of the six mice examined, with an underlying epithelial inflammatory infiltrate composed of PMNs (Figure 5C1,2). Uninfected non-Tg and Tg mice showed an absence of Candida hyphae and inflammatory cell response (Additional file 1).

Compared to uninfected controls at day 7 , infection of non-Tg mice with $C$. albicans significantly $(\mathrm{p}<0.05)$ enhanced tongue tissue expression of S100a8, Ccl20, Il17, $I l 22$ and, to a lesser degree, of the $D f b 3$ gene (Figure 6). In striking contrast, the heightened expression of these genes in response to Candida infection was completely abrogated in untreated control Tg mice, with the exception of Defb3 which showed a modest increase $(\mathrm{p}<0.05)$
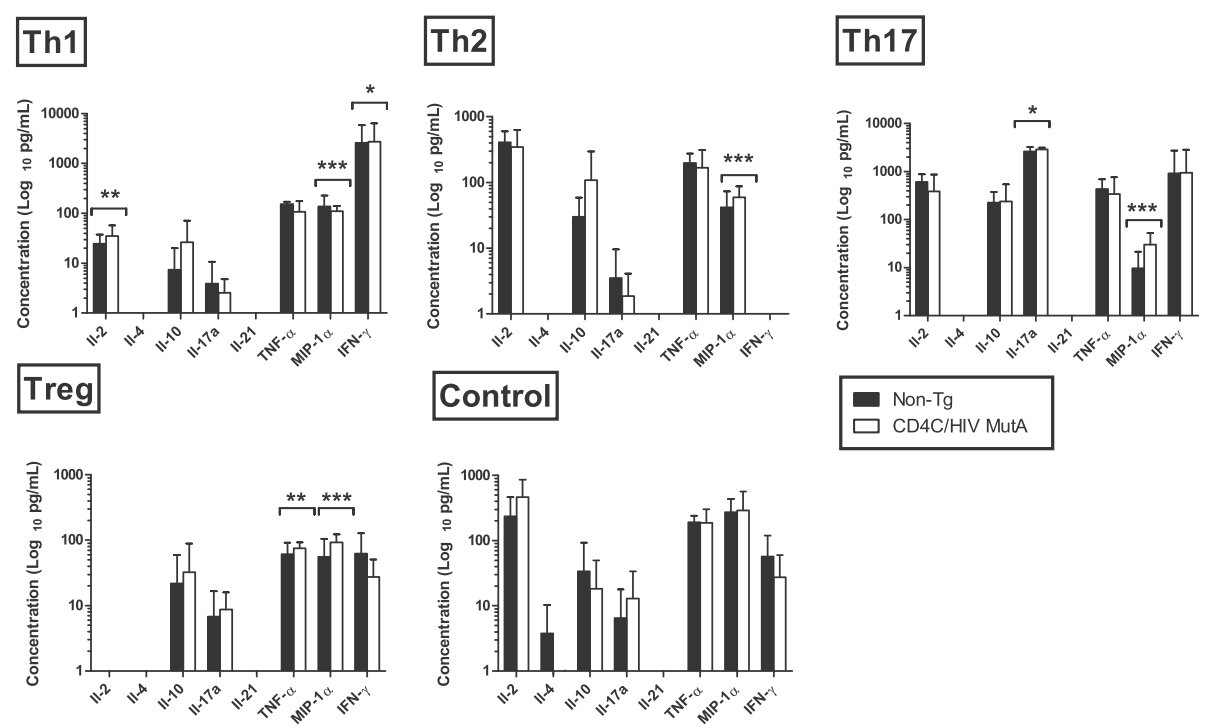

Figure 3 Cytokine production in supernatants of CD4+ T-cell subsets polarized in vitro. Naive CD4+ precursors were harvested from CD4C/HIV MutA $\mathrm{Tg}$ and non-Tg mice, and incubated with (Th1, Th2, Th17, Treg) or without (control) subset-specific differentiating cytokines and blocking antibodies. *, significantly greater $(p<0.05)$ than the other subsets and control; **, significantly lower $(P<0.05)$ than the other subsets and control; ***, significantly lower $(\mathrm{p}<0.05)$ than control. In all differentiating conditions, production of IL-1 $\beta$ and IL-6 was undetectable. Data are mean \pm SD of 6 independent experiments. 

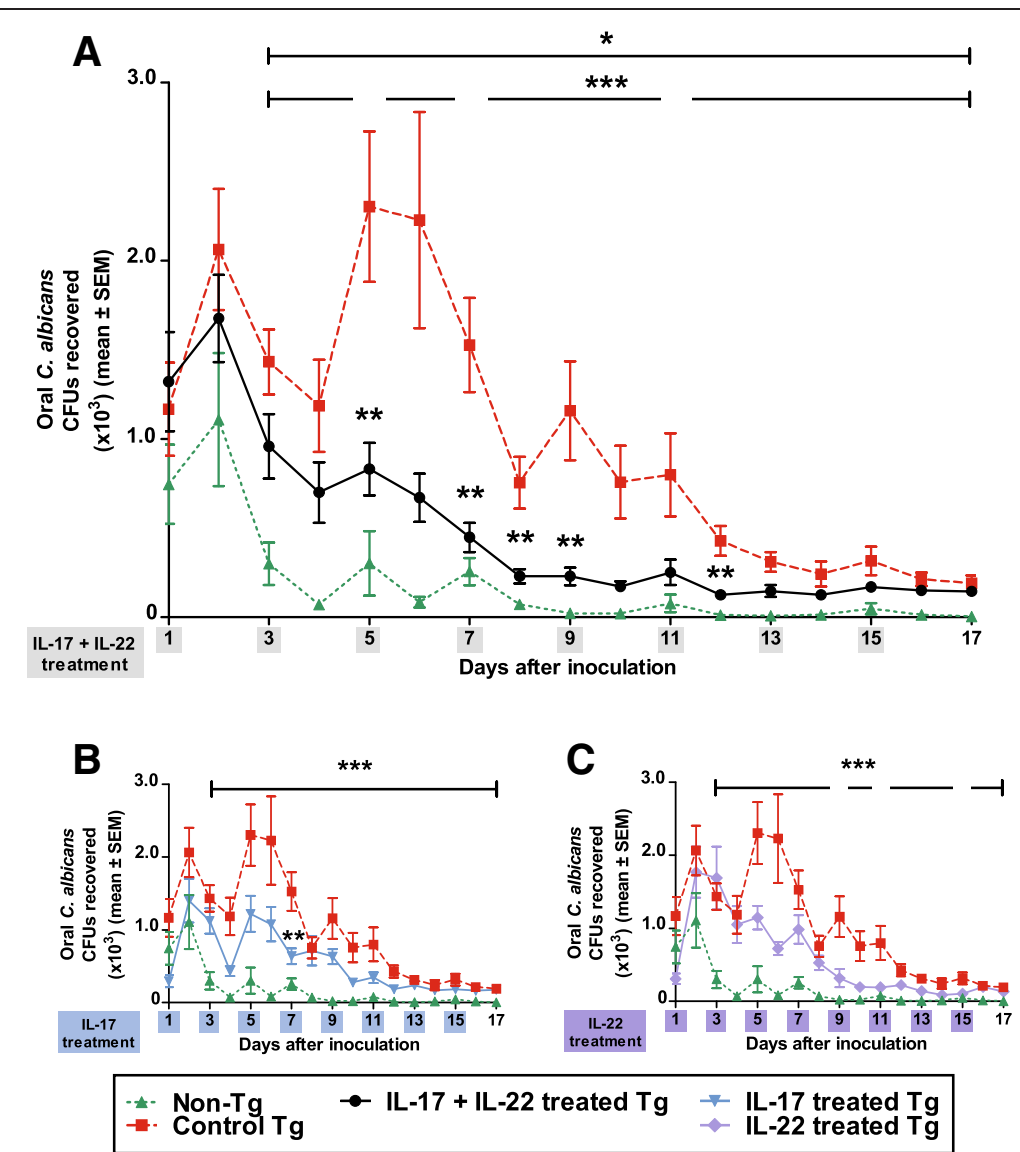

Figure 4 Oral burdens of $C$. albicans strain LAM-1 in CD4C/HIV MutA $\mathrm{Tg}$ mice and non-Tg control mice. Tg mice were treated or not with the combination of IL-17 and IL-22 (A) or with IL-17 or IL-22 alone (B, C). ${ }^{*}, p<0.05$ control Tg vs. control non-Tg; ${ }^{* *}, p<0.05$ treated Tg vs. control Tg; ${ }^{* * *}, p<0.05$ treated Tg vs. control non-Tg. Data are the means \pm SD of results from 10 to 22 mice per group.

comparable to that of the infected non-Tg mice ( $\mathrm{p}>0.05)$ (Figure 6). Consistent with the reduced oral burdens of C. albicans, combined treatment with IL-17 and IL-22 restored the ability of the $\mathrm{Tg}$ mice to up-regulate expression of $\$ 100 a 8, C c l 20$ and $I l 22$ in response to C. albicans infection, to a level not significantly different from infected non-Tg mice ( $>$ > 0.05) (Figure 6). Expression of Ccl2 was unaffected by transgene expression, Candida infection or cytokine treatment at this time point after oral inoculation.

\section{Discussion}

Discovery of the critical role of Th17 cell-dependent mucosal host responses in protection against oral candidiasis [45,46], and the depletion of this cell population in HIVinfected patients [27-30,32-34,47-49], have together suggested that defective Th17-dependent responses to $C$. albicans determine susceptibility to OPC in the setting of HIV infection [50,51]. However, direct experimental evidence in support of this hypothesis has been lacking. Taking advantage of a model of oral candidiasis in transgenic mice expressing HIV-1 [39], which display an
AIDS-like disease [52], we here show that defective IL17- and IL-22-dependent induction of oral antimicrobial peptide expression in response to $C$. albicans infection is indeed central to the phenotype of susceptibility to OPC in these HIV-transgenic mice.

In previous work, we found that $\mathrm{CD} 4+\mathrm{T}$-cells are depleted in the oral mucosa, CLNs and peripheral blood of $\mathrm{CD} 4 \mathrm{C} / \mathrm{HIV}^{\mathrm{MutA}} \mathrm{Tg}$ mice, that CD4+ cells harvested from $\mathrm{Tg}$ mice 7 days after infection fail to proliferate and to acquire an effector phenotype in response to C. albicans antigen in vitro, and that transfer of CD4+ T-cells from uninfected non-Tg mice into infected $\mathrm{Tg}$ mice restores cell proliferation and sharply reduces oral burdens of C. albicans [40]. The present data show that naïve CD4+ T-cells and the polarized subsets, including Th17 cells, are all depleted in these $\mathrm{Tg}$ mice and together contribute to the observed diminution of total CD4+ T-cells. Mechanistically, CD4+ cell depletion in these Tg mice has been shown to result from impaired selection and lineage commitment of CD4+ single-positive thymocytes [53], and an activated memory-like phenotype that exhausts the T-cell pool [54]. Consistent with our previous 

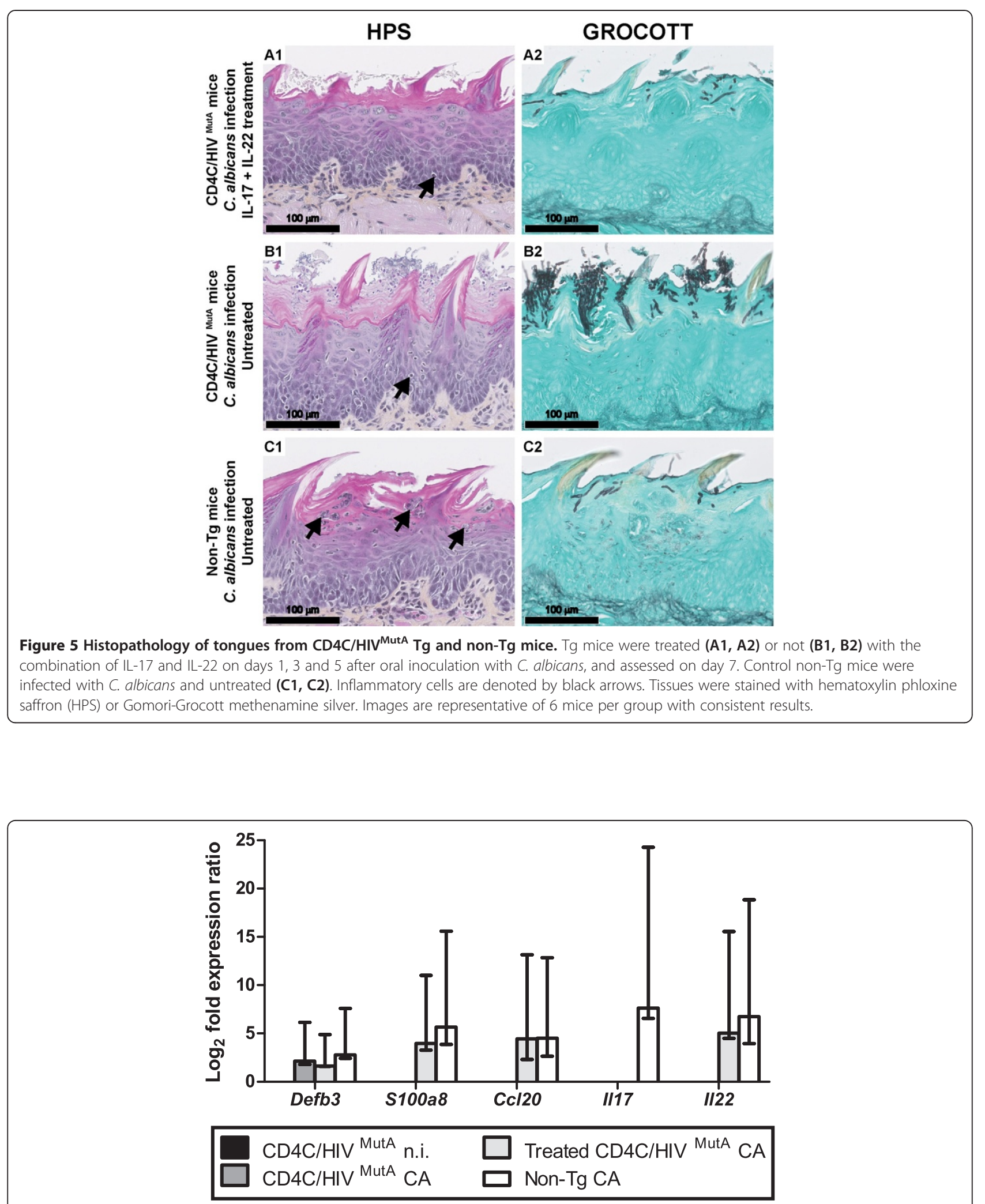

Figure 6 Expression levels of Defb3, S100a8, Ccl20, II17 and II22 genes in tongue tissue. Tg mice were treated or not with the combination of IL-17 and IL-22 on days 1, 3 and 5 after oral inoculation with C. albicans, and RNA was extracted from tongue tissue on day 7. Ccl2 did not display significant differences of expression under any of the experimental conditions (data not shown). Bars represent the mean \pm standard error range of significantly $(p<0.05)$ up-regulated genes, compared to control uninfected non-Tg mice. Data are from 5 mice. 
observations 7 days after infection with C. albicans [40], absolute numbers of CD4+ T-cells were augmented in the CLNs of non-Tg, but not of Tg mice, at this time point. Although absolute numbers of the Th1, Th2, Th17 and Th1Th17 subsets were all increased in CLNs of infected non-Tg mice compared to uninfected controls, this increase only reached statistical significance for the Th2 subset. Nevertheless, these aggregate results indicate that C. albicans infection induces a broad expansion of CD4+ cell subsets in control non-Tg mice, that is abrogated in infected Tg mice.

Although depleted in absolute numbers, the proportion of Tregs relative to total CD4+ cells was enhanced in Tg compared to non-Tg mice. This Treg enrichment is the direct result of HIV-1 Nef expression in CD4+ T-cells, occurs independently of Nef-induced lymphopenia, and involves multiple mechanisms: lower apoptosis, enhanced cell division, and increased generation from precursors [55]. Consistent with our findings, studies in HIV-infected patients have also reported a relative increase in frequency but reduced absolute numbers of Tregs [56-60]. In addition, the late depletion of Tregs in CLNs of the Tg mice, at 70 but not 7 days, concurs with the preserved numbers of Tregs in lymph nodes during acute SIV infection [61].

Having established that the Th17 and other CD4+ cell subsets are depleted in the $\mathrm{Tg}$ mice, we next showed that this depletion does not result from an inability of naïve CD4+ cells from Tg mice to differentiate into the expected CD4 + cell subsets when incubated with polarizing cytokines in vitro. Therefore, the depletion of polarized CD4+ T-cell subsets is most likely caused by the marked diminution of naive CD4+ cells which we found in the Tg mice, rather than any potential downstream defects in CD4+ cell differentiation. Naïve CD4+ T-cells are also depleted in human HIV infection [62-64].

In vitro differentiation of naïve $\mathrm{CD} 4+\mathrm{T}$-cells from control non-Tg mice induced expression of the expected subset-specific signature genes. The enhanced expression of $\mathrm{Il} 21$ by cells from $\mathrm{Tg}$ and non-Tg mice under Th1, Th2 and Th17 polarizing conditions confirms that this cytokine can be produced not only by Th17 cells but also by other subsets including Th1 and Th2 cells [65-68]. Although HIV-1 transgene expression did not inhibit subset polarization and expression of the expected signature genes, it nevertheless altered gene expression profiles of cells incubated in the presence of differentiating cytokines. In cells from the $\mathrm{Tg}$ mice, induction of $A h r$ in Th17 and Treg differentiation conditions is consistent with the known activation of the NF$\kappa B$ pathway by the HIV Nef protein [69], which in turn enhances $A h r$ expression [70]. For their part, naïve CD4 + cells from non-Tg mice, polarized under Th17 conditions, displayed significantly lower expression of Foxp3 compared to cells from Tg mice. Because naive CD4+ cells were polarized in vitro without APCs, it is unlikely that the enhanced Foxp3 expression in Th17-polarized cells from $\mathrm{Tg}$ mice, compared to non-Tg animals, resulted from induction of IDO by HIV-1 Nef. However, we cannot exclude the possibility that prior in vivo exposure of naïve cells to increased IDO activity, before harvesting from the Tg mice, may have sufficed to alter the balance of Th17 and Treg signature genes in vitro. Interestingly, Foxp3 expression is increased in gut-associated lymphoid tissue of untreated HIV-infected patients [57].

Despite these alterations in gene expression induced by the HIV-1 transgene, it is noteworthy that cytokine production in supernatants of in vitro differentiated CD4+ cell subsets was nevertheless comparable in $\mathrm{Tg}$ and non-Tg mice. Accordingly, the differentiated CD4+ cell subsets maintained this critical functional capacity despite HIV-1 transgene expression. Of direct relevance to host defense against C. albicans, production of IL-17 under Th17 differentiation conditions in vitro was unaffected by transgene expression.

Consistent with previous studies conducted in immunocompetent mice $[11,12,71]$, oral infection with $C$. albicans induced expression of S100a8, Ccl20, Il17 and Il22 in tongue tissues of the non-Tg mice. However, this mucosal immune response to $C$. albicans infection was completely abrogated in the $\mathrm{Tg}$ mice. Treatment of infected $\mathrm{Tg}$ mice with the combination of IL-17 and Il-22 by the intraperitoneal route every 2 days for 14 days significantly reduced oral burdens of $C$. albicans, markedly decreased the density of $C$. albicans on histopathology of the oral epithelium, and restored the expression of S100a8 and Ccl20. The cytokine dosage of $3 \mu \mathrm{g}$ was selected because it is at the upper end of the range of dosages $(0.5-3 \mu \mathrm{g})$ previously administered to mice by the intraperitoneal route without undesirable effects [72-75]. Because this combined cytokine treatment did not fully reduce oral burdens of $C$. albicans to levels in the non-Tg mice, we cannot exclude the possibility that a further reduction may be achievable with daily treatment, or by increasing the cytokine dosage to the maximum tolerated dose, to be determined by dose-ranging studies. Alternately, the defects of mucosal immunity which cause susceptibility to OPC in the $\mathrm{Tg}$ mice could partially involve Th1 effector mechanisms [51] which are IL-17- and IL-22-independent. The requirement for combined treatment with both IL-17 and IL-22 to restore mucosal immunity to $C$. albicans extends in vitro studies which showed that IL-22 in conjunction with IL-17 additively enhance the expression of S100A8 by keratinocytes [15]. The mechanism of this cooperation between IL-17 and IL-22 for induction of antimicrobial peptides is unknown but may be the result of convergence of the STAT3 and NF-kB pathways [18]. Although studies in $\mathrm{IL}-22^{\mathrm{KO}}$ and IL-17RA ${ }^{\mathrm{KO}}$ mice have shown that IL-22 
has a significant but lesser protective role than IL-17 in OPC [11], the present results demonstrate that neither cytokine is dispensable for protection against OPC in the context of HIV transgene expression. This paradigm is likely applicable to other susceptible hosts, such as patients with chronic mucocutaneous candidiasis who exhibit reduced production of IL-17 and IL-22 [76].

Consistent with a previous report [11], expression of Defb3 was induced by oral $C$. albicans infection in the non-Tg mice. However, in contrast to $S 100 a 8$, expression of Defb3 was not significantly diminished in the Tg mice, despite the fact that expression of Defb3 and S100a8 is induced by the same cytokines, including IL-17 and IL22 [14-16]. Future work will be needed to examine the signaling pathways leading to induction of Defb3 and S100A8 in the Tg mice $[14,18,77]$.

Our data indicate that the protective effect of IL-17 and IL-22 treatment was most likely mediated by induction of S100a8 in the Tg mice. Calprotectin has been shown to be crucial for clearance of Candida infection [78], is produced at higher levels in patients with OPC [79], but is decreased by HIV infection [80]. No discernible influx of PMNs was induced by the cytokine treatment. This is expected on the part of IL-22, which does not act on immune cells [16] and is uninvolved in PMN recruitment to the oral mucosa in murine candidiasis [11]. Although IL-17-dependent PMN recruitment has been demonstrated in murine $\mathrm{OPC}$, these observations were done 5 days after primary oral infection with $C$. albicans [11]. Early [81] and more recent [12] studies of experimental murine OPC have consistently shown that the early PMN influx is maximal at 24-72 h after infection with C. albicans and is largely replaced by mononuclear cells after day 7 of infection. Therefore, the lack of involvement of PMNs in the protective response to cytokine treatment which we found at day 7 after primary C. albicans infection of the $\mathrm{Tg}$ mice may more closely mimic the reality of the hostpathogen interaction found in HIV-infected patients with established OPC, and provides evidence to support the concept that the mobilization of PMNs may not be the primary underlying mechanism by which IL-17 mediates antifungal effects at this stage of infection [35].

Although we have shown that defective IL-17 and IL22 mucosal responses are involved in the susceptibility of the $\mathrm{Tg}$ mice to OPC, these observations do not in themselves fully explain the progressive reduction in oral burdens in untreated Tg mice from day 5 to 17 after $C$. albicans infection, concluding with a lack of effect of cytokine treatment from day 13 to 17 . In fact, these observations suggest the participation of IL-17producing cell populations other than Th17 cells in the response to $\mathrm{OPC}$ in the $\mathrm{Tg}$ mice, which could potentially include $\gamma \delta$ T-cells, NKT cells, Tc17 CD8 T-cells, and innate lymphoid cells $[33,44,82]$. Indeed, evidence has been presented that IL-17-producing cells other than classic CD4+ Th17 cells protect from OPC in CD4-deficient hosts [35]. Of the potential IL-17-producing cell populations, $\gamma \delta$ T-cells and NKT cells have been shown to not contribute significantly to IL-17 immunity in the oral mucosa $[11,71]$. However, CD8+ T-cells are protective in OPC [11], and we have previously shown that CD8+ Tcells accumulate in the oral mucosa of the Tg mice in response to C. albicans [40] and compensate in part for the loss of CD4+ T-cells [83]. It will therefore be relevant to further characterize these cells and determine if they belong to the Tc17 phenotype. Of note, IL-17-producing innate lymphoid cells [71] may also be an alternative source of this cytokine in the Tg mice, considering that this cell population is depleted in the jejunum but not the oral mucosa of SIV-infected macaques [84,85].

\section{Conclusion}

This study shows that susceptibility to OPC in HIVtransgenic mice is caused by a defective IL-17 and IL22-mediated response to $C$. albicans, producing a loss of mucosal antimicrobial peptide-mediated protective immunity.

\section{Methods}

Generation of Tg mice expressing HIV-1 and animal model of candidiasis

The Tg mice expressing Nef, Env, and Rev of HIV-1 in CD4+ T-cells, DCs, and macrophages (CD4C/HIV ${ }^{\text {MutA }} \mathrm{Tg}$ mice) have been described elsewhere [52]. CD4C/HIV ${ }^{\text {MutA }}$ mutant DNA harbors mouse CD4 enhancer and human CD4 promoter elements to drive the expression of HIV-1 genes in $\mathrm{CD} 4+\mathrm{CD} 8+$ and $\mathrm{CD} 4+$ thymocytes, in peripheral CD4+ T-cells, and in macrophages and DCs. Founder mouse F21388 was bred on the $\mathrm{C} 3 \mathrm{H}$ background. Animals from this line express moderate levels of the transgene, with 50\% survival at 3 months [52]. Several HIV-1 genes (Gag, Pol, Vif, Vpr, Tat and Vpu) are mutated in the CD4C/HIV ${ }^{\text {MutA }}$ DNA, whereas Env, Rev and Nef are intact. The generation of $\mathrm{CD} 4 \mathrm{C} / \mathrm{HIV}^{\text {MutG }}$ mice revealed that selective expression of the Nef gene is required and sufficient to elicit an AIDS-like disease in these Tg mice [52]. This disease is characterized by failure to thrive, wasting, severe atrophy and fibrosis of lymphoid organs, a preferential depletion of CD4+ T-cells, with altered CD4+ T-cell proliferation in vitro, loss of CD4+ T-cell help, CD4+ Tcell and B-cell activation and impaired DC maturation and function [42,52-54,86,87]. In addition, disease of the lung (lymphocytic interstitial pneumonitis), heart (myocytolysis, myocarditis), and kidney (segmental glomerulosclerosis, tubulointerstitial nephritis, microcystic dilatation) develop in these Tg mice $[52,88]$.

Specific-pathogen-free male and female $\mathrm{Tg}$ mice and non-Tg littermates were housed in sterilized individual 
cages equipped with filter hoods, supplied with sterile water, and fed with sterile mouse chow. All animal experiments were approved by the Animal Care Committee of the University of Montreal (protocol 12-088; Additional file 2).

Oral inoculation with C. albicans LAM-1, a clinical isolate, was done as described elsewhere [39,81]. In brief, mice were inoculated by topical application of $10^{8}$ pelleted blastoconidia recovered on sterile calcium alginate Calgiswabs (Puritan Medical Products, Guilford, ME). A longitudinal quantification of C. albicans in the oral cavity of individual mice was done from day 1 until euthanizing of the animals. Calgiswabs used for sampling were dissolved in $2 \mathrm{~mL}$ of Ringer's citrate buffer and plated on Sabouraud dextrose agar supplemented with chloramphenicol $(0.05 \mathrm{~g} / \mathrm{L})$. Plates were incubated for $24 \mathrm{~h}$ at $37^{\circ} \mathrm{C}$, and data were expressed as oral C. albicans colony forming units recovered.

\section{Flow cytometry analysis of $\mathrm{CD} 4+\mathrm{T}$-cell subsets}

Single-cell suspensions of CLNs and spleen were prepared as previously described [40]. Cells were surface stained with four fluorochrome-labelled antibodies (CD4-FITC, CXCR3-PERCP-CY5.5, CCR4-APC, CCR6-PE; BioLegend, San Diego, CA) and their respective isotype controls to specifically identify the Th1, Th2, Th1Th17 and Th17 subsets (Additional file 3). Chemokine receptors CCR4, CCR6 and CXCR3 are surface markers for the functionally distinct Th1 (CXCR3 + CCR6-), Th2 (CCR4+CCR6-), Th17 (CCR4+, CCR6+), and Th1Th17 (CXCR3 + CCR6+) memory CD4+ T-cell subsets $[25,29]$. As a positive control for CCR4, CCR6 and CXCR3 identification of these subsets, splenic CD4+ T-cells were enriched to $>90 \%$ purity by negative selection (Mouse CD4+ T-Cell Enrichment Kit; Stemcell Technologies, Vancouver, BC) and differentiated in vitro into Th1, Th2 and Th17 cells using stimulation with anti-CD3 and anti-CD28 antibodies (eBioscience, San Diego, CA) and combinations of cytokines and anti-cytokine antibodies [89]. Regulatory Tcells were quantitated by staining with anti-mouse anti-CD4, anti-CD25 (both BD Biosciences) and antiFoxp3 (eBioscience) fluorescence-labeled monoclonal antibodies and their respective isotype controls (Additional file 3). Cell surface marker analysis was conducted on a FACSCalibur flow cytometer (BD Biosciences) equipped with CellQuest software. Data were acquired for 50,000 events by gating on $\mathrm{CD} 4+$ cells.

\section{Naive CD4+ T-cell sorting}

Single-cell suspensions of spleen were prepared as previously described [40]. Splenic CD4+ T cells were enriched to $>90 \%$ purity by negative selection (Mouse CD4+ TCell Enrichment Kit; Stemcell Technologies, Vancouver, $\mathrm{BC}$ ) and surface stained with anti-mouse anti-CD4, anti-
CD25, anti-CD62L and anti-CD44 fluorescence-labeled monoclonal antibodies and their respective isotype controls (BD Biosciences). Naive CD4+ T-cells (CD4+ CD25- CD62 $\mathrm{L}^{\text {hi }} \mathrm{CD} 44^{\text {lo }}$ ) were sorted using a FACSVantage $\mathrm{SE}$ instrument (BD Biosciences).

\section{CD4+ T-cell differentiation in vitro}

To assay the capacity of CD4+ T-cells from Tg mice to differentiate into specific subsets in vitro, $1 \times 10^{5}$ sorted naive CD4+ T-cells were cultured in $200 \mu \mathrm{l}$ of ISCOVE medium (Wisent) supplemented with $10 \%$ fetal bovine serum (Gibco). Cells were activated with anti-CD3 and anti-CD28 (Dynabeads Mouse T-Activator CD3/CD28; Gibco) for 6 days at $37^{\circ} \mathrm{C}$ and $5 \% \mathrm{CO}_{2}$ in the presence of specific cytokines (eBioscience) and antibodies (BD Biosciences): IL-12, IFN- $\gamma$ (each $10 \mathrm{ng} / \mathrm{ml}$ ) and anti-IL-4 (Th1); IL-4 (5 ng/ml) and anti-IFN- $\gamma$ (Th2); TGF- $\beta$ (5 ng/ml), IL-6 (20 ng/ml), IL-1 $\beta$ (10 ng/ml), IL-21 $(10 \mathrm{ng} / \mathrm{ml}), \mathrm{IL}-23(10 \mathrm{ng} / \mathrm{ml})$, anti-IFN- $\gamma$ and anti-IL-4 (Th17); TGF- $\beta$ ( $5 \mathrm{ng} / \mathrm{ml})$, IL-2 (10 ng/ml) (Treg). After 6 days of incubation, cells were harvested to assay the expression of the Tbet, Ifng, Tnf, Gata3, Stat6, Il4, Il10, Foxp3, Tgfb, Ahr, Rora, Rorc, Il17a, Il17f, Il21 and Il22 genes. RNA was extracted using the RNeasy Plus Mini Kit (Qiagen) according to the manufacturer's protocol, and qRT-PCR was performed for 40 cycles on a RotorGene 6000 instrument (Qiagen). Ubc, B2m and Atp5b were utilized as reference genes (Primerdesign, UK), and data analysis was done using Qiagen REST 2009 software.

To determine cytokine production by the differentiated cells, culture supernatants were also harvested at day 6 and assayed using the BD cytometric bead array Flex Set (BD Biosciences) according to the manufacturer's protocol on a FACSCalibur flow cytometer equipped with BD CellQuest software. Data analysis was performed using BD FCAP array software 3.0.

\section{Administration of IL-17 and IL-22}

To determine if cytokine treatment can restore resistance to $\mathrm{OPC}$ in the $\mathrm{Tg}$ mice, $\mathrm{Tg}$ and control non- $\mathrm{Tg}$ mice were inoculated orally with $C$. albicans. Beginning at day 1 after inoculation, $\mathrm{Tg}$ mice were treated with PBS or $3 \mu \mathrm{g}$ of recombinant IL-17 and/or IL-22 (eBioscience) i.p. every two days for 14 days. Control non-Tg mice were untreated. Oral fungal burdens were determined daily [39] to compare efficacy of treatments.

In separate experiments, $\mathrm{Tg}$ and non- $\mathrm{Tg}$ mice were inoculated or not with C. albicans, and the inoculated $\mathrm{Tg}$ mice were treated or not with the combination of IL-17 and IL22 on days 1, 3 and 5 post-inoculation. On day 7, the mice were euthanized and the tongues were harvested and bisected longitudinally. qRT-PCR was performed to determine expression of the Defb3, S100a8, Il17, Il22, Ccl2 and Ccl20 genes in tongue tissue, normalized to $18 S$, or Gapdh 
and $U b c$. Histopathological examination was performed as described [39].

\section{Statistical analysis}

CD4+ T-cell subset populations and cytokine production were analyzed with IBM SPSS Statistics for Windows version 20 software (IBM, Armonk, NY) using analysis of variance. Qiagen REST 2009 software was used to analyze gene expression results in real-time qRT-PCR. Oral burdens of $C$. albicans were compared using analysis of variance with the Welch correction, followed by the Games-Howell test for multiple comparisons of unequal variances. Differences were considered to be significant at a $p$ value of $<0.05$.

\section{Additional files}

\section{Additional file 1: Histopathology of tongues from control} uninfected and untreated CD4C/HIVMutA Tg and non-Tg mice. Representative histopathology of tongues from uninfected $\mathrm{Tg}$ (E1, E2) and non-Tg mice (D1, D2).

Additional file 2: ARRIVE guidelines checklist. Completed ARRIVE checklist.

Additional file 3: Gating strategies for Th1, Th2, Th1Th17, Th17 and Treg subpopulations. Staining with four fluorochrome-labelled antibodies (CD4-FITC, CXCR3-PERCP-CY5.5, CCR4-APC, CCR6-PE) specifically identifies the Th1, Th2, Th1Th17 and Th17 subsets. Staining with three fluorochrome-labelled antibodies (CD4-PE, CD25-APC, Foxp3-FITC) identifies the Treg subset.

\section{Abbreviations}

CLN: Cervical lymph nodes; OPC: Oropharyngeal candidiasis;

PMN: Polymorphonuclear leukocytes; Tg: Transgenic.

\section{Competing interests}

The authors declare that they have no competing interests.

\section{Authors' contributions}

$\mathrm{ZH}$ and PJ generated the transgenic mice. MG and FA maintained the animal colony. MG carried out the C. albicans inoculations. MG and SS performed flow cytometry cell sorting and analysis. MG carried out naive CD4+ T-cell culture and differentiation, supernatant and cell harvest, cytokine production assays, RNA extraction and GPCR experiments. MG and VCC carried out the IL-17 and IL-22 cytokine treatment as well as the longitudinal oral CFUs sampling. MG, LG and LdeR performed tongue histopathology and analysis. MG and LdeR prepared the manuscript. All authors read and approved the final manuscript.

\section{Acknowledgments}

This work was supported by the Canadian Institutes of Health Research HIV/ AIDS Research Program (grant HOP-41544). Mathieu Goupil is the recipient of a studentship award from the University of Montreal.

We thank Marie-Andrée Laniel for support in maintaining the Tg mouse colony, and Miguel Chagnon for statistical analysis.

\section{Author details}

'Department of Microbiology, Infectious Diseases and Immunology, Faculty of Medicine, University of Montreal, C.P. 6128, succursale Centre-Ville, Montreal, Quebec H3C 3J7, Canada. ${ }^{2}$ Pathology and Cell Biology, Faculty of Medicine, University of Montreal, Montreal, Quebec, Canada. ${ }^{3}$ Medicine, Faculty of Medicine, University of Montreal, Montreal, Quebec, Canada. ${ }^{4}$ Laboratory of Molecular Biology, Clinical Research Institute of Montreal, Montreal, Quebec, Canada. ${ }^{5}$ Division of Experimental Medicine, McGill University, Montreal, Quebec, Canada. ${ }^{6}$ Histology and Molecular Pathology research unit, Institute for Research in Immunology and Cancer, C.P. 6128, succursale Centre-Ville, Montreal, QC H3C 3J7, Canada.

Received: 9 April 2014 Accepted: 16 October 2014

Published online: 26 October 2014

\section{References}

1. Samaranayake $L P$, Holmstrup $P$ : Oral candidiasis and human immunodeficiency virus infection. J Oral Pathol Med 1989, 18(10):554-564.

2. Martins MD, Lozano-Chiu M, Rex JH: Declining rates of oropharyngeal candidiasis and carriage of Candida albicans associated with trends toward reduced rates of carriage of fluconazole-resistant C. albicans in human immunodeficiency virus-infected patients. Clin Infect Dis 1998, 27(5):1291-1294.

3. Sud N, Shanker V, Sharma A, Sharma NL, Gupta M: Mucocutaneous manifestations in $150 \mathrm{HIV}$-infected Indian patients and their relationship with CD4 lymphocyte counts. Int J STD AIDS 2009, 20(11):771-774.

4. Ranganathan K, Hemalatha R: Oral lesions in HIV infection in developing countries: an overview. Adv Dent Res 2006, 19(1):63-68.

5. Fabian FM, Kahabuka FK, Petersen PE, Shubi FM, Jurgensen N: Oral manifestations among people living with HIV/AIDS in Tanzania. Int Dent J 2009, 59(4):187-191.

6. de Repentigny L, Lewandowski D, Jolicoeur P: Immunopathogenesis of oropharyngeal candidiasis in human immunodeficiency virus infection. Clin Microbiol Rev 2004, 17(4):729-759. table of contents.

7. Fidel PL Jr: Candida-host interactions in HIV disease: relationships in oropharyngeal candidiasis. Adv Dent Res 2006, 19(1):80-84.

8. Campo J, Del Romero J, Castilla J, Garcia S, Rodriquez C, Bascones A: Oral candidiasis as a clinical marker related to viral load, CD4 lymphocyte count and CD4 lymphocyte percentage in HIV-infected patients. J Oral Pathol Med 2002, 31(1):5-10.

9. Mercante DE, Leigh JE, Lilly EA, McNulty K, Fidel PL Jr: Assessment of the association between HIV viral load and CD4 cell count on the occurrence of oropharyngeal candidiasis in HIV-infected patients. J Acquir Immune Defic Syndr 2006, 42(5):578-583.

10. Nielsen H, Bentsen KD, Hojtved L, Willemoes EH, Scheutz F, Schiodt M, Stoltze K, Pindborg Jj: Oral candidiasis and immune status of HIV-infected patients. J Oral Pathol Med 1994, 23(3):140-143.

11. Conti HR, Shen F, Nayyar N, Stocum E, Sun JN, Lindemann MJ, Ho AW, Hai JH, Yu JJ, Jung JW, Filler SG, Masso-Welch P, Edgerton M, Gaffen SL: Th17 cells and IL-17 receptor signaling are essential for mucosal host defense against oral candidiasis. J Exp Med 2009, 206(2):299-311.

12. Saunus JM, Wagner SA, Matias MA, Hu Y, Zaini ZM, Farah CS: Early activation of the interleukin-23-17 axis in a murine model of oropharyngeal candidiasis. Mol Oral Microbiol 2010, 25(5):343-356.

13. De Luca A, Zelante T, D'Angelo C, Zagarella S, Fallarino F, Spreca A, lannitti RG, Bonifazi P, Renauld JC, Bistoni F, Puccetti P, Romani L: IL-22 defines a novel immune pathway of antifungal resistance. Mucosal Immunol 2010, 3(4):361-373.

14. Eyerich S, Wagener J, Wenzel V, Scarponi C, Pennino D, Albanesi C, Schaller M, Behrendt H, Ring J, Schmidt-Weber CB, Cavani A, Mempel M, TraidlHoffmann C, Eyerich K: IL-22 and TNF-alpha represent a key cytokine combination for epidermal integrity during infection with Candida albicans. Eur J Immunol 2011, 41(7):1894-1901.

15. Liang SC, Tan XY, Luxenberg DP, Karim R, Dunussi-Joannopoulos K, Collins M, Fouser LA: Interleukin (IL)-22 and IL-17 are coexpressed by Th17 cells and cooperatively enhance expression of antimicrobial peptides. $J$ Exp Med 2006, 203(10):2271-2279.

16. Wolk K, Witte E, Witte K, Warszawska K, Sabat R: Biology of interleukin-22. Semin Immunopathol 2010, 32(1):17-31.

17. Wolk K, Kunz S, Witte E, Friedrich M, Asadullah K, Sabat R: IL-22 increases the innate immunity of tissues. Immunity 2004, 21(2):241-254.

18. Kolls JK, McCray PB Jr, Chan YR: Cytokine-mediated regulation of antimicrobial proteins. Nat Rev Immunol 2008, 8(11):829-835.

19. Peck A, Mellins ED: Precarious balance: Th17 cells in host defense. Infect Immun 2010, 78(1):32-38.

20. van de Veerdonk FL, Marijnissen RJ, Kullberg BJ, Koenen HJ, Cheng SC Joosten I, van den Berg WB, Williams DL, van der Meer JW, Joosten LA Netea MG: The macrophage mannose receptor induces IL-17 in response to Candida albicans. Cell Host Microbe 2009, 5(4):329-340. 
21. Netea MG, Marodi L: Innate immune mechanisms for recognition and uptake of Candida species. Trends Immunol 2010, 31(9):346-353.

22. LeibundGut-Landmann S, Gross O, Robinson MJ, Osorio F, Slack EC, Tsoni SV, Schweighoffer E, Tybulewicz V, Brown GD, Ruland J, Reis e Sousa C: Syk- and CARD9-dependent coupling of innate immunity to the induction of T helper cells that produce interleukin 17. Nat Immunol 2007, 8(6):630-638

23. Drummond RA, Saijo S, Iwakura Y, Brown GD: The role of Syk/CARD9 coupled C-type lectins in antifungal immunity. Eur J Immunol 2011, 41(2):276-281

24. Robinson MJ, Osorio F, Rosas M, Freitas RP, Schweighoffer E, Gross O, Verbeek JS, Ruland J, Tybulewicz V, Brown GD, Moita LF, Taylor PR, Reis e Sousa C: Dectin-2 is a Syk-coupled pattern recognition receptor crucial for Th17 responses to fungal infection. J Exp Med 2009, 206(9):2037-2051.

25. Acosta-Rodriguez EV, Rivino L, Geginat J, Jarrossay D, Gattorno M, Lanzavecchia A, Sallusto F, Napolitani G: Surface phenotype and antigenic specificity of human interleukin 17-producing T helper memory cells. Nat Immunol 2007, 8(6):639-646.

26. Liu Y, Yang B, Zhou M, Li L, Zhou H, Zhang J, Chen H, Wu C: Memory IL-22producing CD4+ $\mathrm{T}$ cells specific for Candida albicans are present in humans. Eur J Immunol 2009, 39(6):1472-1479.

27. Elhed A, Unutmaz D: Th17 cells and HIV infection. Curr Opin HIV AIDS 2010, 5(2):146-150.

28. El Hed A, Khaitan A, Kozhaya L, Manel N, Daskalakis D, Borkowsky W, Valentine F, Littman DR, Unutmaz D: Susceptibility of human Th17 cells to human immunodeficiency virus and their perturbation during infection. $J$ Infect Dis 2010, 201(6):843-854.

29. Gosselin A, Monteiro P, Chomont N, Diaz-Griffero F, Said EA, Fonseca S, Wacleche V, El-Far M, Boulassel MR, Routy JP, Sekaly RP, Ancuta P: Peripheral blood CCR4 + CCR6+ and CXCR3 + CCR6 + CD4+ T cells are highly permissive to HIV-1 infection. J Immunol 2010, 184(3):1604-1616.

30. Prendergast A, Prado JG, Kang YH, Chen F, Riddell LA, Luzzi G, Goulder P, Klenerman P: HIV-1 infection is characterized by profound depletion of CD161+ Th17 cells and gradual decline in regulatory T cells. Aids 2010, 24(4):491-502.

31. Hu H, Nau M, Ehrenberg P, Chenine AL, Macedo C, Zhou Y, Daye ZJ, Wei Z, Vahey M, Michael NL, Kim JH, Marovich M, Ratto-Kim S: Distinct geneexpression profiles associated with the susceptibility of pathogenspecific CD4 T cells to HIV-1 infection. Blood 2013, 121(7):1136-1144.

32. Brenchley JM, Paiardini M, Knox KS, Asher Al, Cervasi B, Asher TE, Scheinberg P, Price DA, Hage CA, Kholi LM, Khoruts A, Frank I, Else J, Schacker T, Silvestri G, Douek DC: Differential Th17 CD4 T-cell depletion in pathogenic and nonpathogenic lentiviral infections. Blood 2008, 112(7):2826-2835.

33. Bixler SL, Mattapallil JJ: Loss and dysregulation of Th17 cells during HIV infection. Clinical dev Immunol 2013, 2013:852418.

34. Kim CJ, McKinnon LR, Kovacs C, Kandel G, Huibner S, Chege D, Shahabi K, Benko E, Loutfy M, Ostrowski M, Kaul R: Mucosal Th17 cell function is altered during HIV infection and is an independent predictor of systemic immune activation. $J$ Immunol 2013, 191(5):2164-2173.

35. Hernandez-Santos N, Gaffen SL: Th17 cells in immunity to Candida albicans. Cell Host Microbe 2012, 11(5):425-435.

36. Conti HR, Gaffen SL: Host responses to Candida albicans: Th17 cells and mucosal candidiasis. Microbes Infect 2010, 12(7):518-527.

37. Weindl G, Wagener J, Schaller M: Epithelial cells and innate antifungal defense. J Dent Res 2010, 89(7):666-675.

38. Khader SA, Gaffen SL, Kolls JK: Th17 cells at the crossroads of innate and adaptive immunity against infectious diseases at the mucosa. Mucosal Immunol 2009, 2(5):403-411.

39. de Repentigny L, Aumont F, Ripeau JS, Fiorillo M, Kay DG, Hanna Z, Jolicoeur P: Mucosal candidiasis in transgenic mice expressing human immunodeficiency virus type 1. J Infect Dis 2002, 185(8):1103-1114.

40. Lewandowski D, Marquis M, Aumont F, Lussier-Morin AC, Raymond M, Senechal S, Hanna Z, Jolicoeur P, de Repentigny L: Altered CD4+ T cell phenotype and function determine the susceptibility to mucosal candidiasis in transgenic mice expressing HIV-1. J Immunol 2006, 177(1):479-491.

41. Hanna Z, Priceputu E, Chrobak P, Hu C, Dugas V, Goupil M, Marquis M, de Repentigny $L$, Jolicoeur P: Selective expression of human immunodeficiency virus Nef in specific immune cell populations of transgenic mice is associated with distinct AIDS-like phenotypes. J Virol 2009, 83(19):9743-9758.
42. Poudrier J, Weng X, Kay DG, Hanna Z, Jolicoeur P: The AIDS-like disease of $\mathrm{CD} 4 \mathrm{C} /$ human immunodeficiency virus transgenic mice is associated with accumulation of immature CD11bHi dendritic cells. J Virol 2003, 77(21):11733-11744.

43. Espinosa $V$, Rivera $A$ : Cytokines and the regulation of fungus-specific CD4 T cell differentiation. Cytokine 2012, 58(1):100-106.

44. Akdis M, Palomares O, van de Veen W, van Splunter M, Akdis CA: TH17 and TH22 cells: a confusion of antimicrobial response with tissue inflammation versus protection. J Allergy Clin Immunol 2012, 129(6):1438-1449.

45. McGeachy MJ, McSorley SJ: Microbial-induced Th17: superhero or supervillain? J Immunol 2012, 189(7):3285-3291.

46. Glocker EO, Grimbacher B: Mucosal antifungal defence: IL-17 signalling takes centre stage. Immunol Cell Biol 2011, 89(8):823-825.

47. Alvarez Y, Tuen M, Shen G, Nawaz F, Arthos J, Wolff MJ, Poles MA, Hioe CE: Preferential HIV infection of CCR6+ Th17 cells is associated with higher levels of virus receptor expression and lack of CCR5 ligands. J Virol 2013, 87(19):10843-10854.

48. He Y, Li J, Zheng Y, Luo Y, Zhou H, Yao Y, Chen X, Chen Z, He M: A randomized case-control study of dynamic changes in peripheral blood Th17/Treg cell balance and interleukin-17 levels in highly active antiretroviral-treated HIV type 1/AIDS patients. AIDS Res Hum Retrovir 2012, 28(4):339-345.

49. Peng Q, Wang H, Wang H, Li X, Lu X, Liu L, Zhou B, Chen Z: Imbalances of gut-homing CD4+ T-cell subsets in HIV-1-infected Chinese patients. J Acquir Immune Defic Syndr 2013, 64(1):25-31.

50. Cassone A, Cauda R: Candida and candidiasis in HIV-infected patients: where commensalism, opportunistic behavior and frank pathogenicity lose their borders. Aids 2012, 26(12):1457-1472.

51. Pirofski LA, Casadevall A: Rethinking T cell immunity in oropharyngeal candidiasis. J Exp Med 2009, 206(2):269-273.

52. Hanna Z, Kay DG, Rebai N, Guimond A, Jothy S, Jolicoeur P: Nef harbors a major determinant of pathogenicity for an AIDS-like disease induced by HIV-1 in transgenic mice. Cell 1998, 95(2):163-175.

53. Chrobak P, Simard MC, Bouchard N, Ndolo TM, Guertin J, Hanna Z, Dave V, Jolicoeur P: HIV-1 Nef disrupts maturation of CD4+ T cells through CD4/ Lck modulation. J Immunol 2010, 185(7):3948-3959.

54. Weng X, Priceputu E, Chrobak P, Poudrier J, Kay DG, Hanna Z, Mak TW, Jolicoeur P: CD4+ T cells from CD4C/HIVNef transgenic mice show enhanced activation in vivo with impaired proliferation in vitro but are dispensable for the development of a severe AIDS-like organ disease. J Virol 2004, 78(10):5244-5257.

55. Chrobak P, Afkhami S, Priceputu E, Poudrier J, Meunier C, Hanna Z, Sparwasser $T$, Jolicoeur P: HIV Nef expression favors the relative preservation of $\mathrm{CD} 4+\mathrm{T}$ regulatory cells that retain some important suppressive functions. J Immunol 2014, 192(4):1681-1692.

56. Chevalier MF, Petitjean G, Dunyach-Remy C, Didier C, Girard PM, Manea ME, Campa P, Meyer L, Rouzioux C, Lavigne JP, Barré-Sinoussi F, Scott-Algara D, Weiss L: The Th17/Treg ratio, IL-1RA and SCD14 levels in primary HIV infection predict the T-cell activation set point in the absence of systemic microbial translocation. PLoS Pathog 2013, 9(6):e1003453.

57. Rueda CM, Velilla PA, Chougnet CA, Montoya CJ, Rugeles MT: HIV-induced T-cell activation/exhaustion in rectal mucosa is controlled only partially by antiretroviral treatment. PLoS One 2012, 7(1):e30307.

58. Schulze Zur Wiesch J, Thomssen A, Hartjen P, Toth I, Lehmann C, MeyerOlson D, Colberg K, Frerk S, Babikir D, Schmiedel S, Degen O, Mauss S, Rockstroh J, Staszewski S, Khaykin P, Strasak A, Lohse AW, Fätkenheuer G, Hauber J, van Lunzen J: Comprehensive analysis of frequency and phenotype of T regulatory cells in HIV infection: CD39 expression of FoxP3+ T regulatory cells correlates with progressive disease. J Virol 2011, 85(3):1287-1297.

59. Arruvito L, Sabatte J, Pandolfi J, Baz P, Billordo LA, Lasala MB, Salomon H, Geffner J, Fainboim L: Analysis of suppressor and non-suppressor FOXP3+ T cells in HIV-1-infected patients. PLoS One 2012, 7(12):e52580.

60. Moreno-Fernandez ME, Presicce P, Chougnet CA: Homeostasis and function of regulatory T cells in HIV/SIV infection. J Virol 2012, 86(19):10262-10269.

61. Chase AJ, Sedaghat AR, German JR, Gama L, Zink MC, Clements JE, Siliciano RF: Severe depletion of CD4+ CD25+ regulatory T cells from the intestinal lamina propria but not peripheral blood or lymph nodes during acute simian immunodeficiency virus infection. J Virol 2007, 81(23):12748-12757. 
62. Roederer M, Dubs JG, Anderson MT, Raju PA, Herzenberg LA, Herzenberg LA: CD8 naive T cell counts decrease progressively in HIV-infected adults. J Clin Invest 1995, 95(5):2061-2066.

63. Sieg SF, Bazdar DA, Lederman MM: Impaired TCR-mediated induction of Ki67 by naive CD4+ T cells is only occasionally corrected by exogenous IL-2 in HIV-1 infection. J Immunol 2003, 171(10):5208-5214.

64. Rodriguez B, Bazdar DA, Funderburg N, Asaad R, Luciano AA, Yadavalli G, Kalayjian RC, Lederman MM, Sieg SF: Frequencies of FoxP3+ naive T cells are related to both viral load and naive $T$ cell proliferation responses in HIV disease. J Leukoc Biol 2011, 90(3):621-628.

65. Liu Y, Yang B, Ma J, Wang H, Huang F, Zhang J, Chen H, Wu C: Interleukin21 induces the differentiation of human Tc22 cells via phosphorylation of signal transducers and activators of transcription. Immunology 2011, 132(4):540-548.

66. Wurster AL, Rodgers VL, Satoskar AR, Whitters MJ, Young DA, Collins M, Grusby MJ: Interleukin 21 is a T helper (Th) cell 2 cytokine that specifically inhibits the differentiation of naive Th cells into interferon gamma-producing Th1 cells. J Exp Med 2002, 196(7):969-977.

67. Pallikkuth S, Parmigiani A, Pahwa S: The role of interleukin-21 in HIV infection. Cytokine Growth Factor Rev 2012, 23(4-5):173-180.

68. Nurieva $R$, Yang XO, Martinez G, Zhang Y, Panopoulos AD, Ma L, Schluns $K$, Tian Q, Watowich SS, Jetten AM, Dong C: Essential autocrine regulation by IL-21 in the generation of inflammatory T cells. Nature 2007 448(7152):480-483

69. Varin A, Manna SK, Quivy V, Decrion AZ, Van Lint C, Herbein G, Aggarwal BB: Exogenous Nef protein activates NF-kappa B, AP-1, and c-Jun N-terminal kinase and stimulates HIV transcription in promonocytic cells. Role in AIDS pathogenesis. J Biol Chem 2003, 278(4):2219-2227.

70. Champion S, Sauzet C, Bremond P, Benbrahim K, Abraldes J, Seree E, Barra Y, Villard PH: Activation of the NF kappa B pathway enhances AhR expression in intestinal caco-2 cells. ISRN Toxicol 2013, 2013:792452.

71. Gladiator A, Wangler N, Trautwein-Weidner K, LeibundGut-Landmann S: Cutting edge: IL-17-secreting innate lymphoid cells are essential for host defense against fungal infection. J Immunol 2013, 190(2):521-525.

72. Witowski J, Pawlaczyk K, Breborowicz A, Scheuren A, Kuzlan-Pawlaczyk M, Wisniewska J, Polubinska A, Friess H, Gahl GM, Frei U, Jörres A: IL-17 stimulates intraperitoneal neutrophil infiltration through the release of GRO alpha chemokine from mesothelial cells. J Immunol 2000, 165(10):5814-5821

73. Markel G, Bar-Haim E, Zahavy E, Cohen H, Cohen O, Shafferman A, Velan B: The involvement of IL-17A in the murine response to sub-lethal inhalational infection with Francisella tularensis. PLOS One 2010, 5(6):e11176.

74. Wondimu Z, Santodomingo-Garzon T, Le T, Swain MG: Protective role of interleukin-17 in murine NKT cell-driven acute experimental hepatitis. Am J Pathol 2010, 177(5):2334-2346.

75. Mellett M, Atzei P, Horgan A, Hams E, Floss T, Wurst W, Fallon PG, Moynagh PN: Orphan receptor IL-17RD tunes IL-17A signalling and is required for neutrophilia. Nat Commun 2012, 3:1119.

76. Eyerich K, Foerster S, Rombold S, Seidl HP, Behrendt H, Hofmann H, Ring J, Traidl-Hoffmann C: Patients with chronic mucocutaneous candidiasis exhibit reduced production of Th17-associated cytokines IL-17 and IL-22. J Invest Dermatol 2008, 128(11):2640-2645.

77. Steubesand N, Kiehne K, Brunke G, Pahl R, Reiss K, Herzig KH, Schubert S, Schreiber $S$, Folsch UR, Rosenstiel $P$, Arlt A: The expression of the betadefensins hBD-2 and hBD-3 is differentially regulated by NF-kappaB and MAPK/AP-1 pathways in an in vitro model of Candida esophagitis. BMC Immunol 2009, 10:36

78. Urban CF, Ermert D, Schmid M, Abu-Abed U, Goosmann C, Nacken W, Brinkmann V, Jungblut PR, Zychlinsky A: Neutrophil extracellular traps contain calprotectin, a cytosolic protein complex involved in host defense against Candida albicans. PLoS Pathog 2009, 5(10):e1000639.

79. Kleinegger CL, Stoeckel DC, Kurago ZB: A comparison of salivary calprotectin levels in subjects with and without oral candidiasis. Oral Surg Oral Med Oral Pathol Oral Radiol Endod 2001, 92(1):62-67.

80. Sweet SP, Denbury AN, Challacombe SJ: Salivary calprotectin levels are raised in patients with oral candidiasis or Sjogren's syndrome but decreased by HIV infection. Oral Microbiol Immunol 2001, 16(2):119-123.

81. Lacasse M, Fortier C, Trudel L, Collet AJ, Deslauriers N: Experimental oral candidosis in the mouse: microbiologic and histologic aspects. J Oral Pathol Med 1990, 19(3):136-141.
82. Feller L, Khammissa RA, Chandran R, Altini M, Lemmer J: Oral candidosis in relation to oral immunity. J Oral Pathol Med 2013, 43(8):563-569.

83. Marquis M, Lewandowski D, Dugas V, Aumont F, Senechal S, Jolicoeur $P$, Hanna Z, de Repentigny L: CD8+ T cells but not polymorphonuclear leukocytes are required to limit chronic oral carriage of Candida albicans in transgenic mice expressing human immunodeficiency virus type 1. Infect Immun 2006, 74(4):2382-2391.

84. Li H, Reeves RK: Functional perturbation of classical natural killer and innate lymphoid cells in the oral mucosa during SIV infection. Front Immunol 2012, 3:417.

85. Xu H, Wang X, Liu DX, Moroney-Rasmussen T, Lackner AA, Veazey RS: IL-17producing innate lymphoid cells are restricted to mucosal tissues and are depleted in SIV-infected macaques. Mucosal Immunol 2012, 5(6):658-669.

86. Poudrier J, Weng X, Kay DG, Pare G, Calvo EL, Hanna Z, Kosco-Villbois MH, Jolicoeur P: The AIDS disease of CD4C/HIV transgenic mice shows impaired germinal centers and autoantibodies and develops in the absence of IFN-gamma and IL-6. Immunity 2001, 15(2):173-185.

87. Priceputu E, Rodrigue I, Chrobak P, Poudrier J, Mak TW, Hanna Z, Hu C, Kay DG, Jolicoeur P: The Nef-mediated AIDS-like disease of CD4C/human immunodeficiency virus transgenic mice is associated with increased Fas/FasL expression on T cells and T-cell death but is not prevented in Fas-, FasL-, tumor necrosis factor receptor 1-, or interleukin-1 betaconverting enzyme-deficient or Bcl2-expressing transgenic mice. J Virol 2005, 79(10):6377-6391.

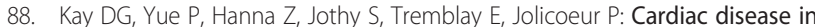
transgenic mice expressing human immunodeficiency virus- 1 nef in cells of the immune system. Am J Pathol 2002, 161(1):321-335.

89. Jin W, Zhou XF, Yu J, Cheng X, Sun SC: Regulation of Th17 cell differentiation and EAE induction by MAP3K NIK. Blood 2009, 113(26):6603-6610.

doi:10.1186/s12865-014-0049-9

Cite this article as: Goupil et al.: Defective IL-17- and IL-22-dependent mucosal host response to Candida albicans determines susceptibility to oral candidiasis in mice expressing the HIV-1 transgene.

BMC Immunology 2014 15:49.

\section{Submit your next manuscript to BioMed Central and take full advantage of:}

- Convenient online submission

- Thorough peer review

- No space constraints or color figure charges

- Immediate publication on acceptance

- Inclusion in PubMed, CAS, Scopus and Google Scholar

- Research which is freely available for redistribution 